Images in...

\title{
Twin presentation of perianal abscess
}

\author{
E W Macharia, ${ }^{1}$ D Griffith, ${ }^{2}$ S N Huddart ${ }^{2}$
}

${ }^{1}$ Department of Paediatric Surgery, Birmingham Children's Hospital, Birmingham, UK

${ }^{2}$ Department of Paediatric Surgery, University Hospital of Wales, Cardiff, UK

Correspondence to E W Macharia,macharia@doctors.org.uk

\section{DESCRIPTION}

We present the case of monochronic dizygotic twins with perianal abscesses coincident in chronology and morphology. This image typifies the features of infant perianal disease that suggest a congenital aetiology.

Twin 1 (weight $3.67 \mathrm{~kg}$ ) and Twin 2 (weight $3.91 \mathrm{~kg}$ ) were admitted to a tertiary paediatric surgical unit on the 34th day of life following a history of perianal abscess at the 11and 10- o'clock positions, respectively (figure 1). This photograph was taken on the 35th day of life. Prior to referral, both patients received oral, then intravenous co-amoxiclav with little local improvement. Incision and drainage was carried out on the 39th (Twin 1) and 35th (Twin 2) day of life, respectively. Escherichia coli (Twin 1) and E Coli and Staphylococcus aureus (Twin 2) were cultured from the abscess pus.

Perianal abscesses are found within $2 \mathrm{~cm}$ of the anal verge and are relatively common in infants (estimated incidence $0.5-4.3 \%$ ). Features suggestive of congenital aetiology are as follows:

1. Majority occur within the first year of life. ${ }^{1}$
2. There is a male preponderance. Fitzgerald et al speculate that an excess of androgen acting on anal glands in utero results in the formation of abnormal glands.

3. Abnormal crypts of Morgagni entrap bacteria leading to abscess formation. Normal crypts are usually shallow (1-2 mm). Shafer et a ${ }^{\beta}$ observed an association between perianal abscess formation and an irregular dentate line with deeper crypts $(8 \mathrm{~mm}$ ) and posited a developmental anomaly during fusion of the dorsal cloacal membrane with the hindgut.

\section{Competing interests None.}

Patient consent Obtained.

\section{REFERENCES}

1. Stites $\mathbf{T}$, Lund DP. Common anorectal problems. Semin Pediatr Surg 2007; 16:71-8.

2. Fitzgerald RJ, Harding B, Ryan W. Fistula-in-ano in childhood: a congenital etiology. J Pediatr Surg 1985;20:80-1.

3. Shafer AD, McGlone TP, Flanagan RA. Abnormal crypts of Morgagni: the cause of perianal abscess and fistula-in-ano. J Pediatr Surg 1987;22:203-4.

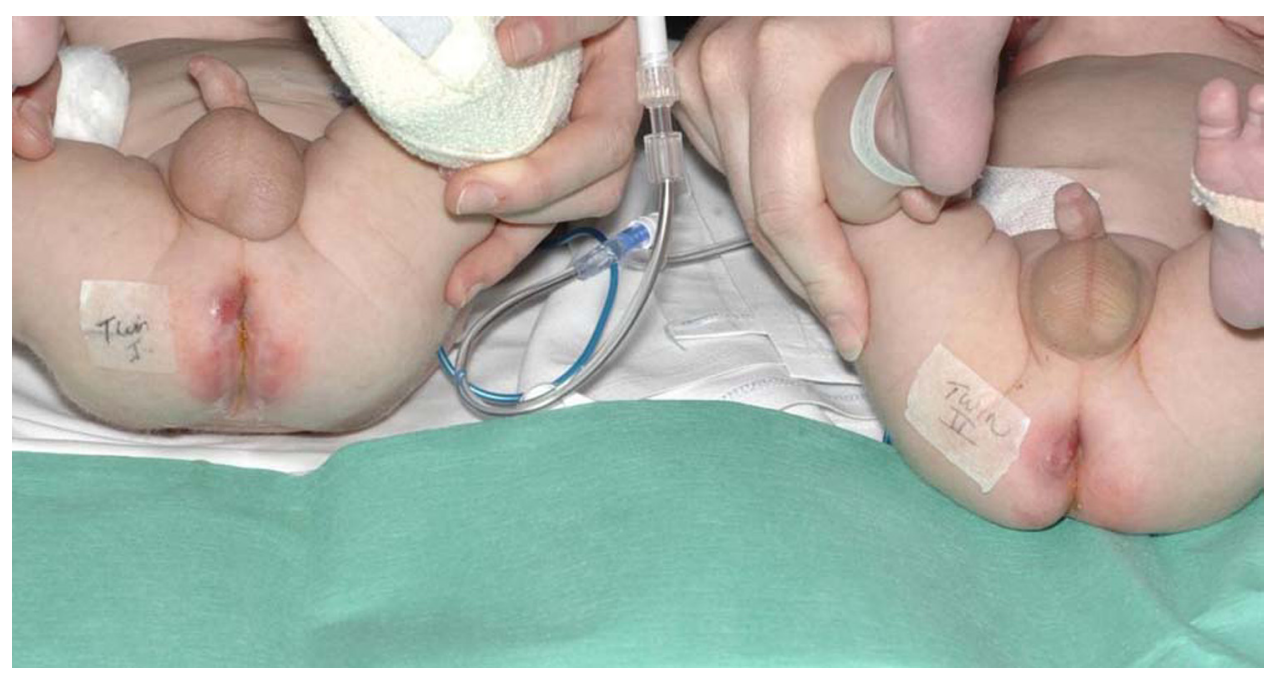

Figure 1 Twin presentation of perianal abscesses in the 11 o'clock (Twin 1) and 10 o'clock (Twin 2) positions, respectively. This picture was taken on day 35 of life. 


\section{BMJ Case Reports}

This pdf has been created automatically from the final edited text and images.

Copyright 2010 BMJ Publishing Group. All rights reserved. For permission to reuse any of this content visit http://group.bmj.com/group/rights-licensing/permissions.

BMJ Case Report Fellows may re-use this article for personal use and teaching without any further permission.

Please cite this article as follows (you will need to access the article online to obtain the date of publication).

Macharia EW, Griffith D, Huddart SN. Twin presentation of perianal abscess. BMJ Case Reports 2010;10.1136/bcr.06.2009.2025, date of publication

Become a Fellow of BMJ Case Reports today and you can:

- Submit as many cases as you like

Enjoy fast sympathetic peer review and rapid publication of accepted articles

Access all the published articles

Re-use any of the published material for personal use and teaching without further permission

For information on Institutional Fellowships contact consortiasales@bmjgroup.com

Visit casereports.bmj.com for more articles like this and to become a Fellow 